\title{
THE INFLUENCE OF GLOBALIZATION ON HIGHER EDUCATION AND THE POTENTIALS OF LEBANON
}

\author{
Bou Diab Anis Nabih, Takieddine, Abir Riad \\ Lebanese University \\ P.O. Box 6573/14 Badaro, Museum, Aley - Lebanon
}

\begin{abstract}
The twentieth century witnessed tremendous increase in the level of globalization and the twenty first century is taking humanity further on this path. Globalization could be defined as the flow of technology, economy, knowledge, people, values, ideas, etc. across borders. It has a great impact on every aspect of human life including higher education. Some scholars describe the twenty first century as the century of educational mobility and global schooling. The term internationalization of education is used a lot these days by educators and is at two levels: internationalization at home and internationalization abroad. Lebanon could benefit tremendously from the global inclination if it could find itself a new role of importer as well as exporter of higher education. It could benefit of its long experience of internationalization at home and of student mobility as well as its cultural diversity and dynamic society to become a provider of education across the borders, both physical and virtual, serving the near region.
\end{abstract}

Key words: Globalization, Higher education, Mobility, Internationalization, Lebanon

\section{Introduction}

"The Age of the Nation is past, it is time to build the Earth" stated the French anthropologist Teihard de Chardin. The twentieth century witnessed tremendous raise in globalization and the twenty first century is taking humanity further on this path. Globalization could be defined as the flow of technology, economy, knowledge, people, values, ideas, etc. across border (Knight J. \& de Wit H., 1997). It has a great impact on every aspect of human life including higher education. Some scholars describe the twenty first century as the century of educational mobility and global schooling (Lee H.C., 2001). The term internationalization of education is used a lot these days by educators and is at two levels: internationalization at home and internationalization abroad. Internationalization at home means the international and intercultural element of the curriculum. It also means the teaching/learning process, research, and extra-curricular activities. In fact, it is a number of activities that help students develop international understanding and intercultural skills without ever leaving the campus (Knight J., 2005). Internationalization abroad means the movement of students, teachers, institutions, curriculum, or programs across the borders and is also known as cross border education. Moreover, education in the twenty first century could be in several cases characterized by the campus-less college, the book-less library, and the professor-less classrooms because 
of distance learning (Lee H.C., 2005). Using distance education processes, students are able to complete part or all of their studies far away from the provider/teacher. They use printed, audio, and video material or the internet to get the material and communicate with their providers (Insung J., 2005).

This paper intends to present the worldwide increasing trend of globalization in higher education and to examine if Lebanon has the necessary framework to face it. It is subdivided into an introduction followed by three sections and a conclusion. The first section discusses how the subject was approached in the literature. The second section presents the adopted methodology. The third section discusses the results of a SWOT analysis performed to assess the situation of Lebanon facing the globalization of the higher education sector. The authors conclude the research with two recommendations to help Lebanon benefit more from the trend of globalization in higher education.

\section{Literature Review}

The article starts with an overview of the literature covering three main issues namely; the paradigm shift facing universities, the role of the WTO in the internationalization of education, and the major views of literature regarding the internationalization of higher education.

\section{The Role of Universities Undergoing a Paradigm Shift}

Higher education institutions are undergoing a paradigm shift trying to cope with the changing environment. Universities are expected to prepare graduates to be global citizen fully equipped to work in a global market (Varghese N.V., 2013), (Varghese N.V., 2011).

\section{Towards More Flexibility and Dynamism}

To serve the globe rather than a nation, universities are recommended to switch from a closed to an open system. In the open system, regulations governing a student from acceptance to graduation are flexible enough to serve a variety of students. The students' body is becoming more diversified coming from different nations, cultural background, age groups, including fresh high-school graduates as well as lifelong learners, full time as well as part time working students. Universities frameworks need to be dynamic enough to continuously overview and update the curriculum keeping an international perspective to match a fast changing international job market. Some scholars even recommend universities administration to strategically manage the institutions by adopting the "clientcentered" rather than "educational-provider" concept in the sense of tailoring their services to match the needs of a diversified students' body (Lee H.C., 2005).

\section{A Variety of Providers Across Borders}

Universities are no longer the only provider of higher education; the sector has changed tremendously during the last fifty years to include a variety of providers across borders. The following section is an overview of the different types of these providers (Knight J., 2005).

Two groups of higher institutions provide education across borders. On the one hand, there are the public, private, or religious institutions which are part of the national 
education system thus accredited by the home nations. On the other hand, there are the non-recognized higher education institutions which are private, profit-oriented and not part of the national education system. Some providers from the second group are of low quality aiming simply at maximizing profits and referred to as "rogue" providers. Since the second group is not part of the national educational system, controlling quality becomes a challenge.

Alternative providers include profit-oriented commercial companies offering courses, programs and support services across the borders. These could be private or publicly traded companies, usually not part of the national education system of the home-nation. Moreover, several companies and higher education institutions could form affiliations to provide education across borders.

The last category of providers includes the virtual institutions that are one hundred percent virtual, profit-oriented, which may or may not be part of the national education system, and are not easily monitored by the system due to their distance delivery methods.

The physical or virtual movement of a provider from a nation to another to offer its services is known as provider mobility and could take several forms (Knight J., 2005). A provider from Lebanon let us say could establish a branch campus in another nation and award qualifications from Lebanon. This provider could, on the contrary, establish an independent institution in the other nation to offer its services. A third way is for the Lebanese provider to purchase a share from a provider already established in the other nation, thus merge. A fourth way is to establish abroad a study center rather than campus to support students. The possibility of offering education across borders is also possible via distance learning by establishing virtual universities.

\section{Programs Mobility}

Education mobility involves programs as well as providers (Knight J., 2005). Franchising is one mode of program mobility where a provider from a source country (I) authorizes another from a host country (II) to offer its courses and programs. Students are awarded qualifications from the source country provider (I). In the case of twinning, students can take courses in the source (I) or host (II) country and be awarded qualification from the provider of the source country (I). Providers from many countries could agree on a common program. Students studying this program will receive a qualification from each provider or a joint degree from all of them. If providers from different countries sign articulations, they give students credits for studies done with any of the providers. A provider from a host country (II) could sign validation agreements with another from a source country (I) allowing it to offer its qualifications. In the distance learning case, students have access to the courses and programs of the source country provider (I) anywhere in the world mainly on-line.

\section{WTO and Cross-Borders Mobility Worldwide}

Internationalization in education existed long ago especially with respect to students' mobility traveling across borders to study (Kritz M., 2012). However, the issue was accentuated when the World Trade Organization (WTO), the only international organization in charge of regulating trade between nations and consisting of 146 nation 
members, discussed in the Uruguay Round the General Agreement on Trade and Services (GATS) which came into effect in $1995^{1}$. It was the first time that the trade of services rather than goods was discussed.

\section{Internationalization of Education Accentuated by the WTO}

According to current commitments of the GATS, foreign services providers will enjoy national treatment and be free to conduct local currency business anywhere in the nation. The educational sector would be open to international competition once the tones for the rules of the game are set under the WTO.

Education was listed in the GATS as one of the services to be traded. The agreement served as a wakeup call for scholars to start actively thinking about the consequences of the liberalization of education. The GATS covers 12 services sectors including education ${ }^{2}$. Trade in education is organized into five categories including primary, secondary, higher, and adults (outside the regular system) education in addition to a fifth category entitled "other education" which includes all other education services not covered elsewhere. In 1995, when the initial commitments of GATS were made, 44 countries (if we consider the European Union as one country) committed to the liberalization of education of which 35 committed to the liberalization of higher education (Knight J., 2005). When a nation agrees to liberate its education sector it has to offer equal and consistent treatment of all trading foreign partners, thus it needs to treat all WTO member nations equally. Moreover, domestic and foreign supplier will be treated equally under this agreement. A nation could decide not to commit all its services sectors and put some limitations on the degree of market accessibility it allows other. However, a nation is obliged to commit to the progressive liberalization. This means that with each negotiation round a nation needs to cover more sectors and eliminate more trade barriers in the already covered sectors ${ }^{3}$.

The GATS defines four modes of supply of any service (Knight J., 2005). The cross border supply mode which consists of providing a service across the nation borders. This mode includes, if applied to the education sector, distance learning, e-learning, and virtual universities. A second mode is the consumption of the service abroad and this is the case of student mobility. The third mode is the commercial presence mode. In this case, the education provider establishes its presence in the host nation by opening a local branch, signing twinning or franchising agreements. A fourth mode is the presence of the natural person which means the movement of the teachers and researchers across the borders.

The cross border education sector is expected to grow worldwide even if a nation refuses to commit to the GATS and this is mainly due to the e-learning and the increasing number of virtual universities.

\section{Cross-Border Mobility levels Worldwide}

Nations nowadays could be classified according to cross-border education into four groups. With respect to the provider/program mobility, a first group consists of developed

\footnotetext{
1 The World Trade Organization, (2017). Access Mode: www.wto.org

2 Ibid.

3 The World Trade Organization. Access Mode: www.wto.org
} 
nations with a strong higher educational sector that are mainly exporter of education such as USA, UK, Australia, and Canada (Insung J., 2005). A second group is of importers of mainly English-language-education such as Japan and Korea (Molly L., 2005). A third group of nations plays the role of both exporters as well as importers such as Hong-Kong. A fourth group of mainly underdeveloped nations are still not active at both import and export levels.

The worldwide demand of higher education is expected to triple between 2000 and 2025 from 97 million to 263 millions. Student mobility consisted of two million students in 2000 that studied outside their home and is expected to grow to 8 millions in 2025 . The top destination of students mobility are USA (22\%), UK (11\%), China (8\%), Germany (7\%), France (7\%), Australia (6\%), China (6\%), Canada (6\%), and Japan $(3 \%)^{1}$.

\section{Major Views on the Internationalization of Higher Education}

The internationalization of higher education is debated by scholars all over the world. Some academics fully support this trend, others oppose it, and a thirds group admits that it is a fact to be dealt with (MED, 1999) $)^{2}$ (University of Oxford, 2015) ${ }^{3}$.

\section{The Supporters}

The group fully supporting this trend argues that the internationalization of education both at home or abroad will help create a knowledge society thus help further develop the human capital. Education providers will be triggered to continuously update their curriculum to prepare their graduates to work in a diversified international job market. Researchers would select topics with an international scope and will be capable thanks to the information technology development to collaborate with scholars across the globe. Information will spread fast creating a kind of "knowledge web" across the world (Lee H.C., 2005). Students and teachers will be more innovative and knowledge will be the most valuable resource of any nation. The world will be moving more and more towards the knowledge economy.

Knowledge emphasized is mainly the know-how (ability to do things and gain skills), the know-why (about the natural world, society, and human mind), and the know-who (social relations) rather than the know-what (knowledge of facts) (MED, 1999) ${ }^{4}$. Learning will be continuous at the level of the organization and firms are to create a learning environment and appreciate its intellectual capital, the intangible asset, as they appreciate its other tangible assets. A nation will also diffuse its culture and benefit from others experiences too.

1 Atlas of Students Mobility website, (2017): Access Mode: www.atlas.iienetwork.org

2 MED Ministry of Economic Development, (1999), What is Knowledge Economy?, Ernest \& Young, New Zealand.

3 University of Oxford, (2015), International Trends in Higher Education, Oxford, United Kingdom.

${ }^{4}$ MED Ministry of Economic Development, (1999), What is Knowledge Economy?, Ernest \& Young, New Zealand. 


\section{The Opponents}

A second group of academics fully opposes the liberalization of education. They are averse of the creeping of the mentality of the business to the sector of education and refuse that education would be considered as a service like others to be traded. The sector will be dominated by profit-oriented providers who will be concerned by profit rather than quality which put the students at risk of dealing with "rogue" providers since the nation cannot always control the quality offered by the cross-border providers. Moreover, the trade in education will create a new center-periphery situation since it will mostly be unilateral. Developed countries will mainly be the exporters whereas developing countries will play the role of importers. Exporter countries will diffuse their culture and mode of thinking and threaten the importers heritage, culture and national sovereignty. For this group education is a public good and needs to remain a public responsibility.

\section{The Realistic Approach}

This paper argues that the internationalization of education is a fact that could not be avoided. A nation needs to prepare itself to gain from the advantages and avoid the disadvantages. The opening up of the education sector is not an instant action; it is rather a long process that a nation needs to undertake to ensure the quality of the service and maintain its cultural identity. Work is needed for the mutual recognition of degrees between the nations. Internationalization is not to be the transplantation of a foreign program as it is, it is rather its adaptation to the local culture and needs. Interaction is thus needed between the importer and exporter to engage in a win-win situation and avoid educational monopoly.

The UNESCO is playing a key role with the Organization for Economic Cooperation and Development ${ }^{1}$. It published in 2005 a document entitled "The Guidelines for Quality Provision in Cross-border Higher Education ${ }^{2}$. The guidelines are prepared jointly by participants from around 90 countries and have two main concerns: to protect students seeking cross border education from receiving low quality services and to stress the importance of the retention of national sovereignty of higher education which needs to be cultural specific (Antony S., 2005).

Since the internationalization of education is a reality to be dealt with, the fourth and last section of this paper evaluates the readiness of Lebanon to gain from the internationalization of higher education and to face the possible threats arising from the new environment.

\section{Methods and Approaches}

To be able to answer our research question and properly examine whether or not Lebanon has the necessary framework to face the increasing trend of globalization in higher education, the authors decided to build the study on a literature review followed by a SWOT analysis.

\footnotetext{
${ }^{1}$ OECD, (2009), Globalization and Higher Education: What Might the Future Bring?, in Imhe INFO.

2 OECD and UNESCO, (2005), Guidelines for Quality Provision in Cross-border Higher Education.
} 
The literature review is necessary to build a theoretical framework about how was the issue of globalization in higher education tackled by international literature. The higher education sector is moving towards more flexibility and dynamism with many providers crossing the borders. The WTO was identified as a major player in encouraging mobility worldwide. The authors subdivided the literature on the internationalization of higher education into three groups namely; the supporters, the opponents, and the realistic and argued for the third group. The theoretical framework built in the first section would be of great value in the next section consisting of a SWOT analysis.

The SWOT analysis is considered a simple but useful framework for analyzing a situation through identifying its strengths, weaknesses, opportunities and threats. It helps the user focus on the strengths, work on the weaknesses, minimize threats, and take full advantages of opportunities. The SWOT analysis of Lebanon facing the globalization of the higher education sector was performed in the light of the theoretical framework discussed above.

The researchers decided to adopt a mixed approach using qualitative as well as quantitative data to serve the research needs. The research is descriptive in nature. It describes the emerging trend of globalization in higher education worldwide and in Lebanon and deduces some conclusions about Lebanon.

\section{Results: a SWOT Analysis about Lebanon}

Does Lebanon have the necessary education framework to deal with the internationalization of higher education? The internationalization of higher education exposed so far is at two levels: at home and cross-border. The cross border education is an inward or outward movement of students, faculty member, physical, and virtual commercial presence.

It is important to mention first that Lebanon is not a full member of the WTO yet but rather an observer member. Observer members are those expected to join the organization once they make the necessary changes to conform their economy and legal framework to the organization regulations.

\section{Strength}

The strength of Lebanon when it comes to the internationalization of higher education is that it practiced it long ago. The first two higher education providers in Lebanon were private foreign missionary that crossed the border to Lebanon to establish the American University of Beirut (formerly the Syrian Protestant College) by Protestant American missionaries in 1866 and the Saint Joseph University by the Jesuits in 1875. The Beirut Arab University, affiliated to the Alexandria University in Egypt, was later established in 1960. The leader providers of higher education were thus foreigners from the private sector. It was not till the year 1950 that the Lebanese government established the national public university named the Lebanese University.

It needs to be mentioned that there are currently in Lebanon 35 private universities, 9 private colleges, 3 private universities for religious studies and the public Lebanese University $^{1}$. Around $80 \%$ of these institutions were established in the 1990's when the

${ }^{1}$ MEHE Ministry of Education and Higher Education in Lebanon, (2017): Access Mode: www. higher-edu.gov.lb 
Lebanese government decided to expend the sector. The sector includes 180850 students, 16387 teachers, and around 5000 staff members in 2009-2010.

The curriculum was therefore international and intercultural taking the basis of the west and adapted to the east. Internationalization at home was practiced and the Lebanese students looked for such curriculum since many of them migrated to work abroad and wanted to be prepared for international competition. What helped in this process was that the Lebanese population is diversified and multilingual speaking fluently many languages besides its Arabic mother tongue (namely French, English, and Armenian).

The mobility of students inward and outward existed years ago. Foreign students studied at the Saint Joseph University, American University of Beirut, Beirut Arab University, Lebanese American University (formerly Beirut University College), and the Lebanese University. The number of foreign university students in Lebanon decreased during the civil war since foreigners avoided coming to an insecure country. After the war, the numbers boosted again. Today, the number of international students (with a foreign passport) at the American University of Beirut for example is 2000 from 66 different countries out of a total of approximately 5000 students (AUB, 2017) ${ }^{1}$.

Mobility works both ways since many Lebanese students leave Lebanon yearly the study abroad. In 2006, it was estimated that $7.3 \%$ of the Lebanese university students were studying abroad, their top destination is mainly: France with 4671 students, USA with 2179 students, Germany with 976 students, Italy with 577 students, and UK with 575 students (Atlas of Students Mobility, 2008)2 .

Foreign faculty members cross the border to Lebanon to teach mainly at the private universities previously mentioned. Many Lebanese study abroad and stay there teaching at universities too.

\section{Weaknesses}

The major weakness in the Lebanese higher education sector facing globalization is quality assurance in distance learning in particular. This weakness is not unique to Lebanon. All nations around the world are working on improving their quality control measures. The flourishing of cross border education changed the rules of the games by introducing new types of providers and new modes of supply thus necessitate the review of the existing quality control practices. When a student moves across the border to study, the quality of the service he /she gets is controlled by the government that controls the provider. However, when a student gets the service via a distance learning program, he/ she is at risk of dealing with a "rogue" provider since the provider is beyond the scope of the control of the nation in terms of the licensing the institution and the accreditation of the programs . Moreover, there is a need to work on the international recognition of degrees to help graduates from a nation to work in another.

\section{Opportunities}

The opportunities offered to Lebanon are tremendous if it could succeed in finding itself a new role mainly as an importer as well as exporter of education to the region.

\footnotetext{
1 American University of Beirut, (2017): Access Mode: (www.aub.edu.lb).

2 Atlas of Students Mobility website, (2017): Access Mode: (www.atlas.iienetwork.org).
} 
Since most nations are opening up more and more their higher education sector, Lebanon is to grasp the chance to cross the borders and practice outward provider/ program mobility. Lebanese universities could establish their presence mainly in the Arab countries via opening branches, franchising, or merging. Lebanon has to work now on two modes, not only attracting more foreign students to Lebanon but also moving to serve these students in their home country now that the chance is offered.

Moreover, Lebanon needs not only recognize and control virtual education as a new mode of supply, but also seek to become a provider of such type and cater for an increasing demand. This goes hand in hand with a continuous development of telecommunication infrastructure to support this task.

\section{Threats}

The threats facing Lebanon in losing its national identity because of the internationalization in higher education are believed to be minimal since Lebanon is known to be open to different civilizations and religions. In facts, it plays the role of a median between the eastern and western civilization and the uniqueness of Lebanon was long ago due to this specific role. The cultural diversity existing creates a dynamic society capable of fast adaptation to the changing environment.

The major threat, however, is believed to be in Lebanon failing to find itself a new role in this changing environment. The number of foreign students coming to Lebanon might decline since these students will have access to different types of providers/programs at home. Relying on the inward students' mobility is not enough anymore. Lebanon considered itself in the past as the provider of education and other services to the region and mainly to its Arabic fellows. This role could be sustained if and only if Lebanon succeeds in importing as well as exporting higher education. The comparative advantage of Lebanon is its capability of importing foreign curriculum, adapting it to the culture and needs of the region it knows well before exporting it. This necessitates a continuous investigation of the region needs and a permanent update of curriculum.

\section{Conclusion and Recommendations}

After exploring the new trends in higher education worldwide, we conclude that it is moving more and more on the way of internationalization at home and across the borders. Curriculums are made to form an international citizen and students, faculty, and providers are moving across the borders. The distance learning mode is flourishing due to the development in telecommunication. These trends are emphasized by the WTO listing education among the traded services. The challenges facing nations are mainly to ensure the quality of the education provided across borders and to keep education culture specific with an international outlook.

Finally, for Lebanon to benefit from the global inclination, we recommend policy makers and major actors in the field of higher education to work on a) Lebanon finding itself a new role of importer as well as exporter of higher education and $b$ ) helping Lebanon benefit of its long experience of internationalization at home, of student mobility, cultural diversity, and dynamic society to become a provider of education across the borders, both physical and virtual, serving the near region. 


\section{REFERENCES}

Antony, S. (2005). “UNESCO-OECD Guidelines on Quality Provision in Cross-Border Education”, UNESCO Forum Occasional Paper, Korea.

Insung, J. (2005). "Implications of WTO/GATS on Quality Assurance of Distance Learning Education for Higher education”, UNESCO Forum Occasional Paper, Korea.

Knight J. (2005). "Cross-Border Education: Developments and Implications in the Asia and the Pacific Region”, UNESCO Forum Occasional Paper, Korea.

Knight J. \& de Wit H. (Eds.) (1997). Internationalization of Higher Education in Asia and Pacific Countries, European Association for International Education, Amsterdam.

Kritz, M. (2012). Globalization of Higher Education and International Student Mobility, Cornell University, USA.

Lee, H.C. (2005). "UNESCO's Role in the Development of Higher Education of Asia and the Pacific Region in the $21^{\text {st }}$ Century", UNESCO Forum Occasional Paper, Korea.

Lee, H.C. (2001). Universities Going with the $21^{\text {st }}$ Century, Mineum Publisher, Seoul.

MEHE \& TEMPUS (2011). The Lebanese Higher Education System- Short Description, TLQAA Project, Lebanon.

MED Ministry of Economic Development (1999). What is Knowledge Economy?, Ernest \& Young, New Zealand.

Molly, L. (2005). Cross-Border Education in Asia and the Pacific Region: International Framework for Qualification, Forum Occasional Paper, Korea.

Varghese, N.V. (2013). Globalization and Higher Education: Changing Trends in Cross Border Education, Analytical Reports in International Education. Vol. 5. No. 1. Pp. 7-20, December.

Varghese, N.V. (2011). Globalization and Cross-border Education: Challenges for the Development of Higher Education in Commonwealth Countries, UNESCO.

(C) Bou Diab Anis Nabih, Takieddine Abir Riad, 2017

\section{Article history:}

Received: 23 May 2017

Revised: 03 June 2017

Accepted: 08 July 2017

\section{For citation:}

Bou Diab Anis Nabih, Takieddine Abir Riad. (2017) The influence of globalization on higher education and the potentials of Lebanon. RUDN Journal of Economics, 25 (2), 178-188. DOI: 10.22363/23132329-2017-25-2-178-188

\section{Bio Note:}

Bou Diab Anis Nabih. PhD Associate Professor, Head of the Finance Department, Faculty of Economic Sciences \& Business Administration, Lebanese University. Contact information: e-mail: boudiabanis@hotmail.com

Takieddine Abir Riad. PhD, Associate Professor, Faculty of Economic Sciences \& Business Administration, Lebanese University. Contact information: e-mail: abirtaki@hotmail.com 


\title{
ВЛИЯНИЕ ГЛОБАЛИЗАЦИИ НА ВЫСШЕЕ ОБРАЗОВАНИЕ И ПОТЕНЦИАЛ ЛИВАНЦЕВ
}

\author{
Бу Диаб Анис Набих, Такиддин Абир Риад \\ Университет Ливана \\ 6573/14 Бадаро, Аляй - Ливан
}

Глобализацию можно определить как поток технологий, экономики, знаний, людей, ценностей, идей через национальные границы государств. Это оказывает большое влияние на каждый аспект человеческой жизни, включая высшее образование. Некоторые исследователи описывают XXI век как век образовательной мобильности и глобального обучения. Термин интернационализация образования в наши дни широко используется преподавателями и находится на двух уровнях: интернационализация дома и интернационализация за рубежом. Ливан мог бы извлечь огромную выгоду от процессов глобализации, в контексте как импортеров, так и экспортеров на международным рынке образовательных услуг. Также, Ливан мог бы использовать свой многолетний опыт вместе с культурными традициями для продвижения образовательных услуг. В перспективе страна может стать одним из основных поставщиком образовательных услуг, как в классическом виде, так и в интерактивном в своем регионе.

Ключевые слова: глобализация, высшее образование, мобильность, интернационализация, Ливан

\section{История статьи:}

Дата поступления в редакцию: 23 мая 2017

Дата принятия к печати: 08 июля 2017

\section{Для цитирования:}

Бу Диаб Анис Набих, Такиддин Абир Риад. Влияние глобализации на высшее образование и потенциал ливанцев // Вестник Российского университета дружбы народов. Серия: Экономика. 2017. T. 25. № 2. C. 178-188. DOI: 10.22363/2313-2329-2017-25-2-178-188

\section{Сведения об авторах:}

Бу Диаб Анис Набих, кандидат наук, доцент, руководитель департамента финансов факультета «Экономических наук и бизнес администрирования» Университета Ливана. Контактная информация: e-mail: boudiabanis@hotmail.com

Такиддин Абир Риад, кандидат наук, доцент факультета «Экономических наук и бизнес администрирования» Университета Ливана. Контактная информация: e-mail: abirtaki@ hotmail.com 